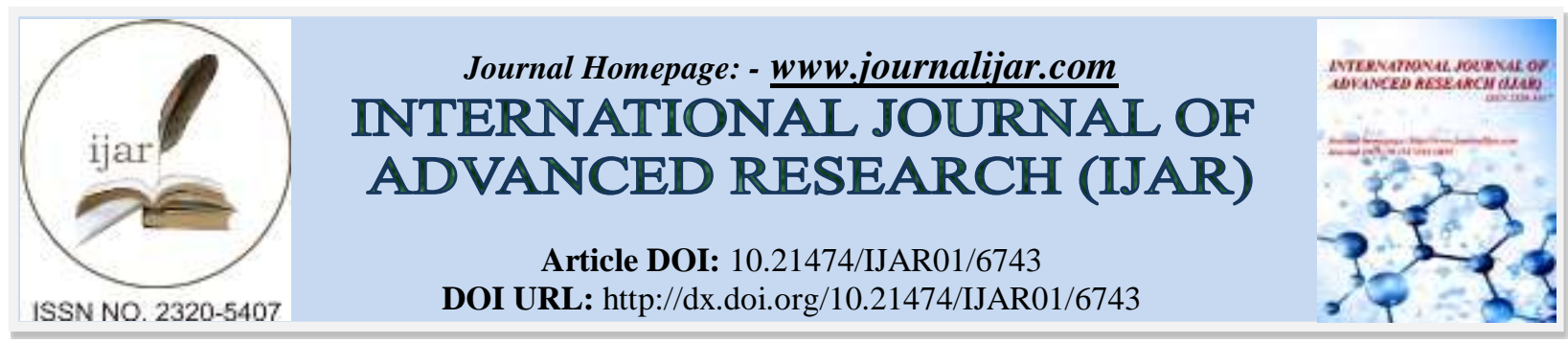

RESEARCH ARTICLE

\title{
CLIMATE CHANGE CHARACTERIZATION IN THE SEMI-ARID ABDA PLAIN IN WESTERN CENTRAL MOROCCO.
}

\author{
Alahiane Kamal $^{1,2}$, El Mzouri El Houssine ${ }^{2}$, El Hani Sliman ${ }^{3}$ and Koulali Yahya ${ }^{1}$. \\ 1. Laboratory of Eco-design, Energy, Environment and Innovation, University Hassan ${ }^{\text {st }}$, Faculty of Sciences and \\ Technology, Settat, Morocco. \\ 2. Department Of Agronomy, Regional Center for Agronomic Research, Settat, Morocco. \\ 3. Department Of Agronomy, Regional Center for Agronomic Research, Tanger, Morocco.
}

\section{Manuscript Info}

[..........................

Manuscript History

Received: 14 January 2018

Final Accepted: 16 February 2018

Published: March 2018

Keywords:-

Climate change, agro-climatic

characterization, Rain-fed cropping

systems, Abda.

\begin{abstract}
The Abda plain is part of the semi-arid areas of Morocco, which are subject to the effects of climate change. Agricultural activities are strongly affected by the repeated droughts in this part of Morocco. There is need for an agro-climatic characterization in order to better help farmers adapt. The objective of this work is to study the evolution pattern and to characterize agro-climatic tendencies in the dryland area of Abda, plain of Morocco. Results of this study show a continuous and significant decline of the total amount of rainfall received by this area, with $108 \mathrm{~mm}$ rainfall decrease over the last 43 years. The average Martonne index calculated during the two distinct period 1975-1996 and 1997-2017 are, respectively 13.9 and 9.4. Indeed, the Standardized Precipitation Index calculated confirm the tendency of droughts period with about $71 \%$, the years were normal and that $29 \%$ were moderately or severe dry years but no wet years during the last two decades. For the length of growth period, a decrease reported during the two last 20 years with a decline from 192 days during the first period to only 138 days during the second period. The year 1996 is the break point for all calculated average indices. In conclusion, this work shows that the rainfall pattern in the dryland area of Abda, plain of Morocco is decreasing with erratic rainfall, high frequencies of severe droughts and reduced crop growth period.
\end{abstract}

Copy Right, IJAR, 2018,. All rights reserved.

\section{Introduction:-}

Climate change and its impact on agriculture is one of the greatest challenges facing humanity in the $21^{\text {st }}$ century. Morocco by its geographical position dominated by the semi-arid bioclimatic zones (more than $85 \%$ of cultivated areas) has shown signs of climate variability during the last decades (Huebener and Kerschgens, 2007). The extension of dry periods became a reality in this part of the globe. Indeed, many investigators reported high frequencies of severe droughts (Sebbar and al., 2012; Sebbar and al., 2011; Meddi, 2009). These droughts are affecting agricultural productivity, activities and sustainability in the dryland semi-arid areas of Morocco. The objective of this work is to study the evolution pattern and to characterize agro-climatic tendencies in the dryland area of Abda, plain of Morocco. 


\section{Materials and Methods:-}

The area covered by this study (Fig.1) is located at the western Morocco (Latitude $32^{\circ} 17^{\prime} 57$, Longitude $-9^{\circ} 14^{\prime} 13$ ). Its climate a Mediterranean climate with hot and dry summers and cold and rainy winters. The agricultural activities are dominated by rain-fed small grain production (wheat and barley) associated with mixed animal husbandry (sheep and cattle).

The climate data (daily rainfall and temperatures were provided by the National Department of Meteorology (DMN). These data covered the period from 1975 to 2017 for Jemâa Shaïm climatic station. The variables generated from this database are:

- Annual rainfall evolution

- $\quad$ Martonne Index (I)

- Standardized Precipitation Index (SPI)

- $\quad$ Length of growth period (LGP)

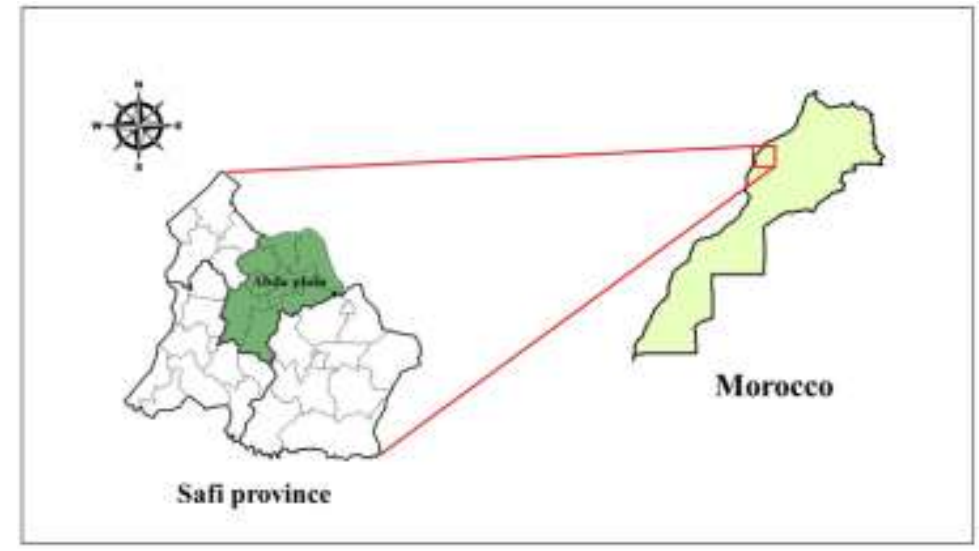

\section{Rainfall evolution:-}

Figure 1:- Localization of study area (in green), Safi province, Morocco

The interannual rainfall evolution were calculated by a yearly data series during the period between 1975 and 2017. These data have been organized, processed and analyzed by using no-parametric Pettit method, Bayesian method of Lee and Heghinian, and the segmentation of Hubert (Lubès and al., 1994). We used the statistical software: Khronostat (1998) developed by the Institute of Research for Development (Lubes-Niel and al., 1998), to analyze the time series and to characterize the evolution, ruptures and the extreme events marked the study area during the period.

\section{Martonne Index:-}

The annual aridity index allows you to define the type of climate of a given area based on the data of rainfall and thermal. This index established by De Martonne, (1923) is calculated by the following equation:

\section{$\mathbf{I}=\mathbf{P} /(\mathbf{T}+\mathbf{1 0})$}

With:

P: The annual total precipitation ( $\mathrm{mm}$ )

T: The annual average temperature $\left({ }^{\circ} \mathrm{C}\right)$

The interpretation of I values is as follows:

- If $\mathbf{I}<\mathbf{1 0}$, the climate is arid

- If $\mathbf{1 0}<$ I $<\mathbf{2 0}$, the climate is semi-arid

- If $\mathbf{2 0}<$ I $<\mathbf{5 0}$, the climate is cold, temperate or tropical

- If $\mathbf{I}>\mathbf{5 0}$, the climate is equatorial or mountain

Similarly, to the rainfall pattern, we used no-parametric Pettit method, Bayesian method of Lee and Heghinian, and the segmentation of Hubert (Lubès and al., 1994).

\section{Standardized Precipitation Index (SPI):-}

Standardized Precipitation Index (McKee and al., 1993) is primarily a tool for defining and monitoring drought events. It determines the rarity of drought at a given time-scale. Its computation involves fitting a gamma probability 
density function to a given frequency distribution of precipitation totals for a climatic station. The mathematical formula of SPI is:

$\mathrm{SPI}=(\mathbf{P i}-\mathbf{P m}) / \sigma$

With:

Pi: Precipitation of the year i

Pm: Mean precipitation

б: Standard deviation

The interpretation of SPI values is as follows:

- SPI > 2.0: Extremely wet

- 1.5 < SPI < 1.99: Wet

- 1.0 < SPI < 1.49: Moderately wet

- -0.99 < SPI < 0.99: Normal

- $-\mathbf{1 . 0}<$ SPI < -1.49: Moderately dry

- $-1.5<$ SPI $<-1.99$ : Dry

- SPI <-2.0: Extremely dry

\section{Length of growth period (LGP):-}

The length of growth period is defined as the period of the year during which the average temperatures is above the optimum temperatures for plants growth (average temperature $>5^{\circ} \mathrm{C}$ ) and during which precipitation exceed one half of the potential evapotranspiration. This method was developed by the FAO in 1978 to determine the positioning of the crops in the agricultural season for given farming area.

\section{Results and discussions:-}

Rainfall evolution:-

The interannual rainfall evolution in Abda area during the period between 1975 and 2017 is characterized by a significant decrease of $28.3 \%$ (3.2 mm/year) (Fig. 2). Two distinct periods are identified, the first one from 1975 to 1996 with an average of $381.5 \mathrm{~mm} / \mathrm{year}$, and the second one from 1997 to 2017 with an average of $273.5 \mathrm{~mm}$. This reduction of $108 \mathrm{~mm}$ of rainfall during the last 43 years, which represent $1 / 3$ of the total amount received in this area. It is very significant decrease when considering the low rain-fed cereal based the cropping system of Abda. Similar results were reported in other rain-fed cereal producing areas of Morocco (Driouech, 2006; Sebbar and al., 2011).
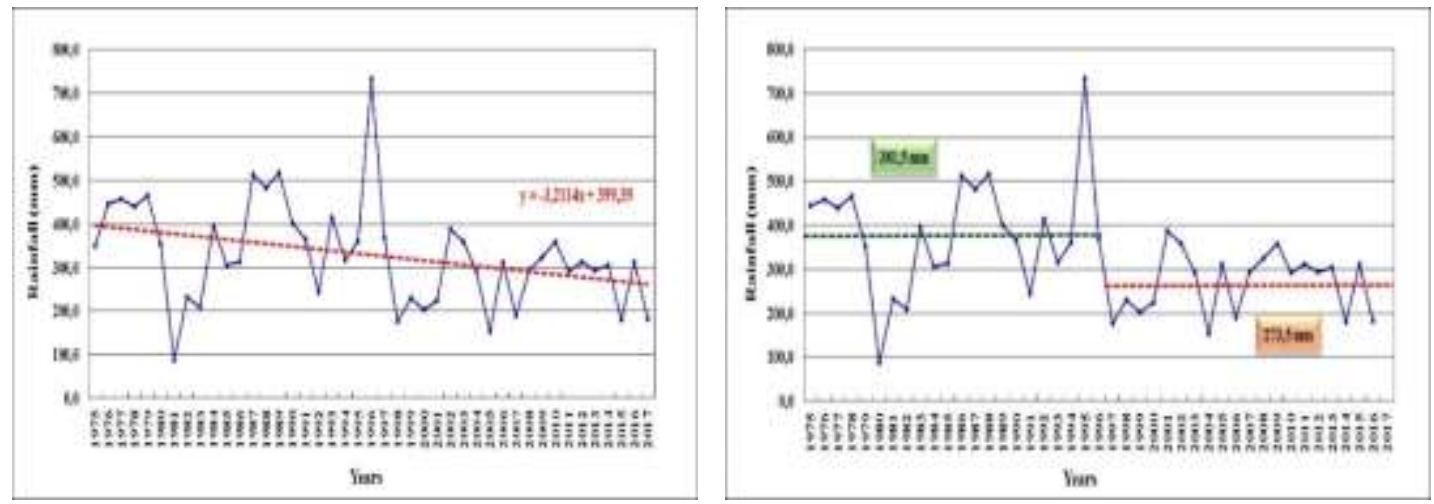

Figure 2:- Evolution of annual rainfall $(\mathrm{mm})$ in Abda area during the last 43 years and the rainfall break point in Abda area

Martonne Index:-

The aridity Martonne index trend between 1975 and 2017 shows a clear decline from 1975 to up-till now. The average indices calculated annually show a sharp decline during the year 1996. In fact, the average index calculated over the 1975-1996 period was about 13.9 whereas the average index for the period 1997-2017 dropped to 9.40 (Fig. 3 ). These results show a clear shift of Abda area from semi-arid climatic zone to an arid one. This trend toward more aridity was reported by Driouech, (2010) and Sebbar \& al., (2012) and demonstrated that aridity is moving northward in Morocco during the last 30 years. 


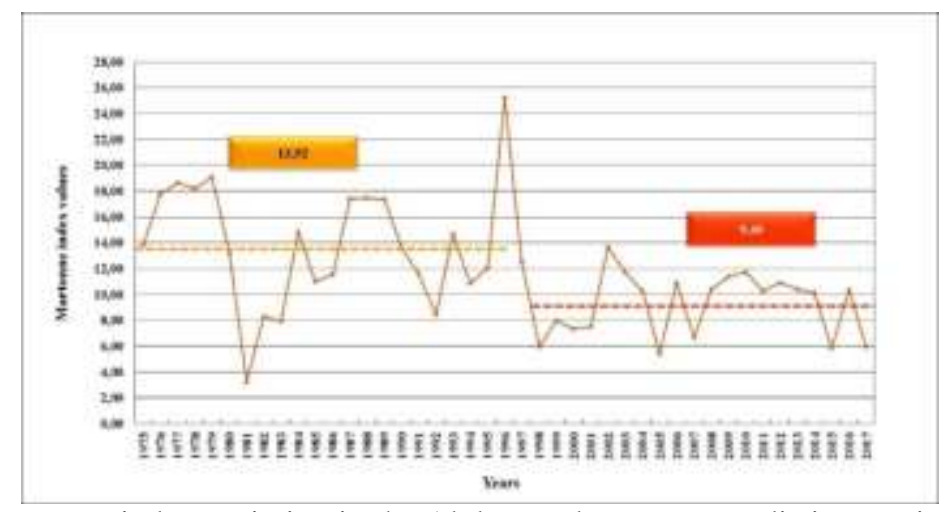

Figure 3: The aridity Martonne index variation in the Abda area between two distinct periods 1975 to 1996 (yellow) and 1997-2017 (red)

\section{Standardized Precipitation Index (SPI):-}

The standardized precipitation index values calculated for the period 1975 and 2017 confirm the previous results and show a clear trend toward more aridity during the last 20 years (Fig. 4). In fact, during the period 1975-1996, Abda area had $63 \%$ of the years that were normal; $27 \%$ were moderately or extremely wet years, and that only $10 \%$ that were moderately or extremely dry years. However, during the second period from 1997 to 2017 , about $71 \%$, the years were normal and that $29 \%$ were moderately or severe dry years but no wet years. Results from this study confirm what was reported by other studies in Morocco (Lachgar and al., 2016; El Bouqdaoui and al., 2006), and demonstrate that rainfall is more erratic with more and more severe droughts that leads to crop failure and loss.

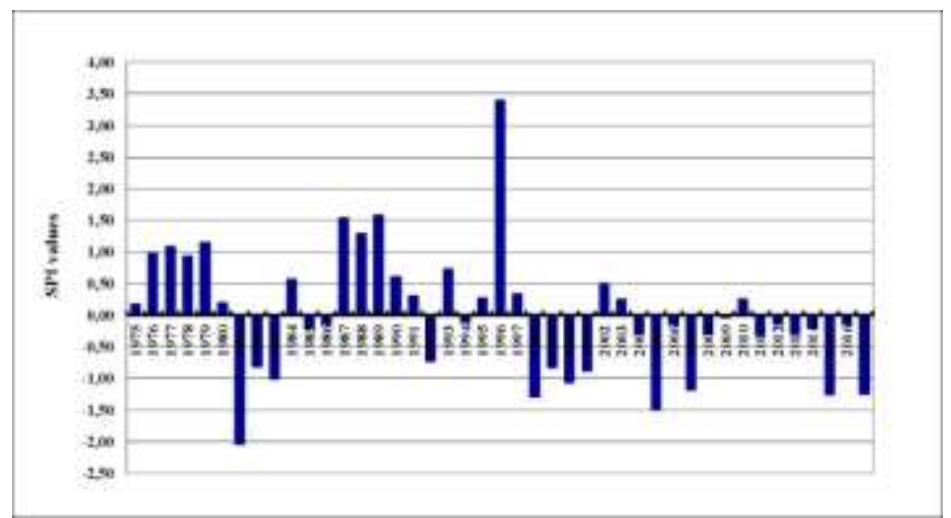

Figure 4:- The standardized precipitation index values variation in the Abda area during the last 43 years.

\section{Length of growth period (LGP):-}

The length growth period (LGP) declined from 192 days during the period 1975-1996 to only 138 days during the period 1997-2017 (Fig. 5), confirming therefore the previous results. Indeed, with the decrease the total amount of rainfall received, and increased aridity with less favorable years, the crop canopy is facing more abiotic stresses (water and heat stresses). This significant decrease of LGP impacts negatively farm activities and farming practices and management currently adopted by local farmers. Among the practices that are the most vulnerable to this LGP changes we cite species and varieties choices, soil tillage, crop rotation, fertilizer management weed and pest management, etc... All this changes will force farmers to find ways to adapt to insure better crop production and stability and therefore more farming sustainability under the dryland semi-arid and arid areas (El Mzouri and al., 2010; Benaouda and al., 2008; Jlibene and Balaghi, 2009; Jlibene and Chafai, 2002). 


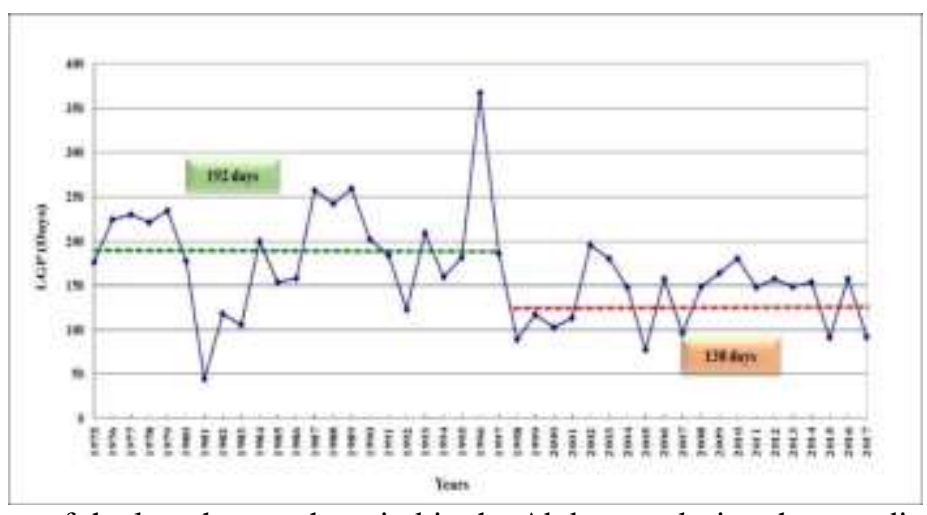

Figure 5 :- The evolution of the length growth period in the Abda area during the two distinct periods 1975-1996 (green) and 1997-2017 (red)

Studies conducted on Moroccan climate explain that two phenomena are behind climatic variability: (1) the North Atlantic Oscillation (NAO), which exerts an important influence on the Moroccan precipitation. The relation between the NAO index and the rainfall is strong but negative correlation. The average index of the North Atlantic Oscillation of the months from September to February, explains the three quarters $\left(\mathrm{R}^{2}=74 \%\right)$ of the national rainfall average variation; and (2), El Niño Southern Oscillation (ENSO) that carries a certain influence on the Moroccan precipitation. The warm phase (positive) of the ENSO phenomenon would lead to a reduction of spring precipitation (Nicholson, 1997; Ward and al., 1999).

\section{Conclusion:-}

The characterization of the agro-climatic conditions in the dryland area of Abda, Morocco shows a continuous and significant decline of the total amount of rainfall received by this area, with $108 \mathrm{~mm}$ rainfall decrease over the last 43 years. The year 1996 is the break point for all calculated average indices. Indeed, before 1996 the Martonne index and the LGP were, respectively 13.9 and 192 days but after this year both variables were respectively, 9.4 and 138 days. We concluded from this work that the rainfall pattern in the dryland area of Abda, plain of Morocco is decreasing with more erratic rainfall, more severe droughts frequencies and reduced crop growth period.

\section{References:-}

1. Benaouda H., El Ouali, E. El Mzouri, A. Chriyaa et Saloui, (2008). Rapport annuel du projet INRA-IDRC, Mécanismes d'adaptation aux changements climatiques des Communautés rurales dans deux écosystèmes contrastés de plaine et de montagne du Maroc, INRA Maroc.

2. De Martonne E., (1926). Aréisme et indice d'aridité. Compt. Rend. Séances Acad. Sci. 181: 1395-1398.

3. Driouech F., (2006). Etude des indices de changements climatiques sur le Maroc : températures et précipitations. DMN "INFOMET", Secrétariat d'Etat auprès du Ministère de l'Energie, des Mines, de l'Eau et de l'Environnement, Chargé de l'Eau et de l'Environnement, Royaume du Maroc, Casablanca.

4. El Bouqdaoui K., M. Aachib, M. Blaghen et S. Kholtei, (2006). Modélisation de l'écoulement de la nappe de Berrechid (Maroc). La Houille Blanche, revue internationale de l'eau 2-2008 : 24-92.

5. El Mzouri E., A. Chriyaa (2010). Rapport annuel du projet INRA-IDRC, Mécanismes d'adaptation aux changements climatiques des Communautés rurales dans deux écosystèmes contrastés de plaine et de montagne du Maroc, INRA Maroc.

6. Huebener, H. \& Kerschgens, M. (2007) Dowscalling of current and future rainfall climatologies for southern Morocco. Part I: Downscalling method and current climatology. Int. J. Climatol. 27, 1763-1774.

7. Jlibene M., A. E. Chafai, (2002). Variétés de blé adaptées au nord-ouest du Maroc. Bulletin de Transfert de Technologie en Agriculture ${ }^{\circ} 88.4 \mathrm{p}$.

8. Jlibene M., R. Balaghi, (2009). Le risque sécheresse en agriculture pluviale. Bulletin mensuel de liaison et d'information du Programme National de Transfert de Technologie $n^{\circ} 181$.

9. Lachgar, R., H. El Hadi, G. Zahour and Y. Daki, (2016). Caractérisation de la Sécheresse climatique du Bassin versant d'Oum Er Rbia (Maroc) par le biais de l'indice de précipitation standardisé (SPI), 12 (14), 198-209.

10. Lubès H., J.M. Masson, E. Servat, J.E. Paturel, B. Kouamé and J.F.Boyer, (1994). ICCARE : rapport no 3 : caractérisation de fluctuations dans une série chronologique par applications de tests statistiques : étude bibliographique. Montpellier: ORSTOM, 22 p. 
11. Lubès-Niel H., J. M. Masson, J. E. Paturel and E. Servat, (1998). Variablité climatique et statistique. Etude par simulation de la puissance et de la robustesse de quelques tests utilisés pour vérifier l'homogénéité de chroniques. Revue des Sciences de l'Eau 11(3), 383-408.

12. MCKee T.B., N.J. Doesken, J. Kleist, (1993). The relationship of drought frequency and duration to time scales, Proceedings of the 8th Conference on Applied Climatology, 17-22 January 1993, Anaheim, California, 179-184.

13. Meddi H., (2009). Variabilité des précipitations annuelles du Nord-Ouest de l'Algérie. Sécheresse, 20(1), 57-65.

14. Nicholson S.E., (1997). An analysis of the ENSO signal in the tropical Atlantic and western Indian Oceans. Int. J. Climatol. 17, 345-375.

15. Nicholson S.E., (1997). An analysis of the ENSO signal in the tropical Atlantic and western Indian Oceans. Int. J. Climatol. 17, 345-375.

16. Sebbar A., H. Fougrach, M. Hsain, A. Saloui, W. Badri, (2011). Etude de la variabilité du régime pluviométrique au Maroc septentrional (1935 - 2004). Sécheresse, 22, 139-48.

17. Sebbar A., H. Fougrach, M. Hsain, W. Badri, (2012). Etude des variations climatiques de la région Centre du Maroc. Actes du colloque de l'Association Internationale de Climatologie, Grenoble. 709-714.

18. Ward M.N., P.J. Lamb, D.H. Portis, M. El Hamly and R. Sebbari, (1999). Climate Variability in Northern Africa: Understanding Droughts in the Sahel and the Maghreb. - Chapter 6in: Beyond el Niño--decadal and interdecadal climate variability. Ed.: A.Navarra. Springer Verlag, 119-140. 